\title{
Del af eller uden for fællesskabet? - rummet som medskaber af uformelle læreprocesser
}

Tina Bering Keiding, lektor, Center for Undervisningsudvikling og Digitale Medier, Aarhus Universitet.

\section{Reviewet artikel}

Artiklen undersøger studerendes læringsoplevelser $i$ projektorganiseret undervisning $i$ individuelle grupperum og $i$ åbent kontorlandskab. Den konkluderer, at de to studiemiljøer skaber vidt forskellige læringsoplevelser. Det åbne rum tilbyder rige muligheder for inspiration og feedback og bidrager til fagligt og socialt tilhørsforhold. Endvidere synes det åbne rum at skabe bedre rammer for udvikling af lærings- og samarbejdskompetencer. De lukkede rum vanskeliggør både formel og uformel kontakt og giver mange studerende en oplevelse af at stå uden for frellesskabet.

\section{Rummet som den tredje pædagog? - rammesætning og forskningsspørgsmål}

Didaktikken beskæftiger sig altovervejende med, hvad der kan betegnes som studiemiljøets sociale arkitektur. Det sker gennem spørgsmålene om, med hvilket formål der skal undervises (undervisningens hensigt), hvad der skal undervises i, og i hvilken rækkefølge (undervisningens indhold og sekvenser), samt hvorledes interaktionen mellem deltagerne skal organiseres (undervisningens metoder og medier) (Helmke, 2009; Meyer, 2005).

Derimod har didaktikken traditionelt kun i begrænset omfang haft opmærksomheden rettet mod de fysiske rammers betydning for undervisningen. Nogle få eksempler fra dansk forskning, hvor rummet anskues specifikt i relation til undervisning og læring, er Ricken (2010), som tilbyder en række eksempler fra grundskolen på rummets betydning for undervisningen og elevernes læringsaktiviteter; Kirkeby (2003) som fokuserer på universitetsbyggeri samt Larsen (2005), hvor rummets pædagogiske betydning beskrives i en række forskellige kontekster og hvor især to bidrag har særlig relevans for denne artikel. Det drejer sig om Kirkeby, Gitz-Johansen og Kampmann (2005), som fokuserer på samspillet mellem rum og hverdagsliv i skolen set både ud fra et arkitekturfagligt synspunkt og ud fra elevernes oplevelser og forståelse af rummene samt bidraget fra Winther, som blandt andet beskriver ho- 
veddøren som overgangen mellem den offentlige og private zone (Winther, 2005, p. 226-228). Gutman \& de Coninck-Smith (2008) tilbyder både arkitekturfaglige, sociologiske og børnecentrerede perspektiver på barndommen og dens materielle kultur, og de Coninck-Smith (2011) tilbyder en skole- og arkitekturhistorisk analyse af skolen og de forventninger og ønsker til barndommen, som byggeriet formidler.

Ser man på nyere universitets- og skolebyggerier, ses en klar tendens mod fysisk åbne og blødt programmerede rum ${ }^{1}$ (UBST, 2009; Horst \& Misfeldt, 2010). Dette kan både tolkes som ambitioner om at optimere udnyttelsen af bygningsmassen gennem rumlig fleksibilitet; som forsøg på at fremtidssikre til nye undervisningsformer samt ses som udtryk for et ønske om at intensivere interaktionen mellem rummenes brugere. Et eksempel på sidstnævnte er Watson (2006, s. 8): “The Saltire Centre is a building for people that provides inspirational space for interaction, conversation and learning" samt beskrivelsen af det såkaldte "Superlab" på London Metropolitan University (London Metropolitan University, i.å.), hvor der tales om, at de fysiske rammer skal give de studerende en "cutting edge experience of learning science".

Også på arkitektur- og designuddannelserne på Aalborg Universitet knyttes forventninger til, at rummet har betydning for de studerendes læringsoplevelser. Præmissen er her, at fælles tegnesale bidrager til, at de studerende lærer af hinanden (Keiding, 2011a, p. 198). Både på denne uddannelse og i forhold til uddannelsesbyggeri generelt (bl.a. de Coning-Smith, 2011; Watson, 2006) knyttes således forventninger til, at det fysiske miljø kan mediere inspirerende og læringsstimulerende interaktion. Det skal med andre ord tjene en didaktisk funktion. Men hvorledes oplever de studerende det? Hvilken interaktion har de med hinanden, og hvilken betydning tilskriver de studerende interaktionen i forhold til såvel egen læring som til deres aktuelle projekt? Kan disse åbne og fleksible studiemiljøer tjene en didaktisk funktion?

Målet med denne artikel er at belyse og diskutere disse spørgsmål med afsæt i et mindre, komparativt studie af studerendes oplevelse af interaktionen, sådan som den udfolder sig mellem projektgrupper placeret i henholdsvis individuelle grupperum og i et åbent miljø med flere grupper.

\section{Analysestrategi}

Det empiriske grundlag er et casestudie foretaget på Aalborg Universitets uddannelse i arkitektur og design, første semester 2007. Semesteret består dels af en række kurser, dels af 2 gruppeprojekter. Projektformen er mere udførligt beskrevet i Kei-

\footnotetext{
${ }^{1}$ Distinktionen mellem blødt og hårdt programmerede rum benyttes bl.a. af forfatteren i Keiding (2010). Et blødt programmeret rum er et rum, hvor udformning og indretning åbner for, at rummet kan benyttes på mange forskellige måder, mens et hårdt programmeret rum er udformet med få aktiviteter for øje (fx et auditorium).
} 
ding \& Laursen (2008). I studieåret 2007/2008 blev det som følge af et optag på ca. 130 studerende nødvendigt at placere $7 \mathrm{ud}$ af $\mathrm{i}$ alt 15 grupper i et tidligere undervisningslokale, i det følgende betegnet som multigrupperum (forkortet MGR). De øvrige grupper blev placeret i de traditionelle individuelle grupperum, betegnet som singlegrupperum (forkortet SGR).

Denne situation gav en unik mulighed for at sammenligne de studerendes oplevelser med to forskellige studiemiljøer. I både første og anden projektperiode blev grupperummene fordelt ved lodtrækning. Det betød, at nogle studerende fik erfaringer med begge rumtyper, mens andre var placeret i samme rumtype i begge projektperioder.

Som det fremgår af illustrationerne, adskiller de to rumtyper sig primært med hensyn til selve rummets afgrænsning og de ydre omgivelser.

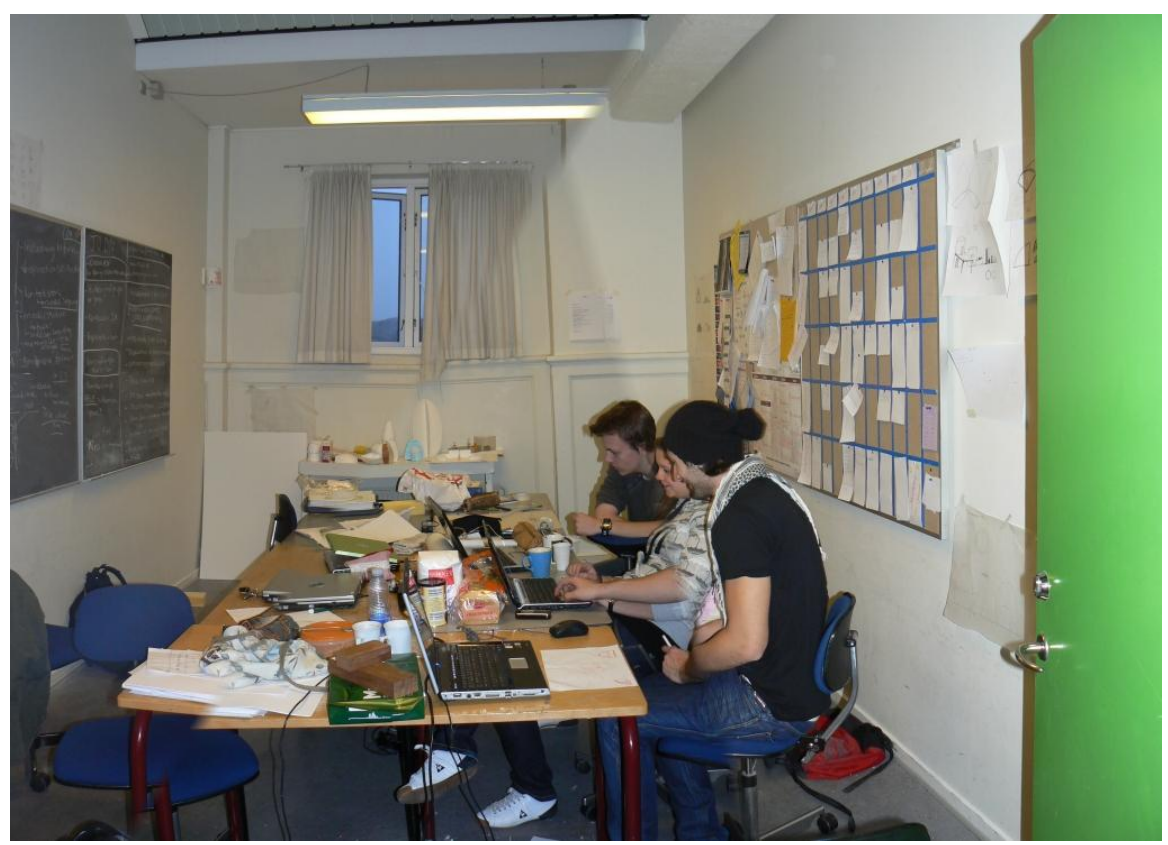

Figur 1. Et individuelt lukket grupperum (SGR). Rummet har faste vægge og dør ud til frlles korridor. 


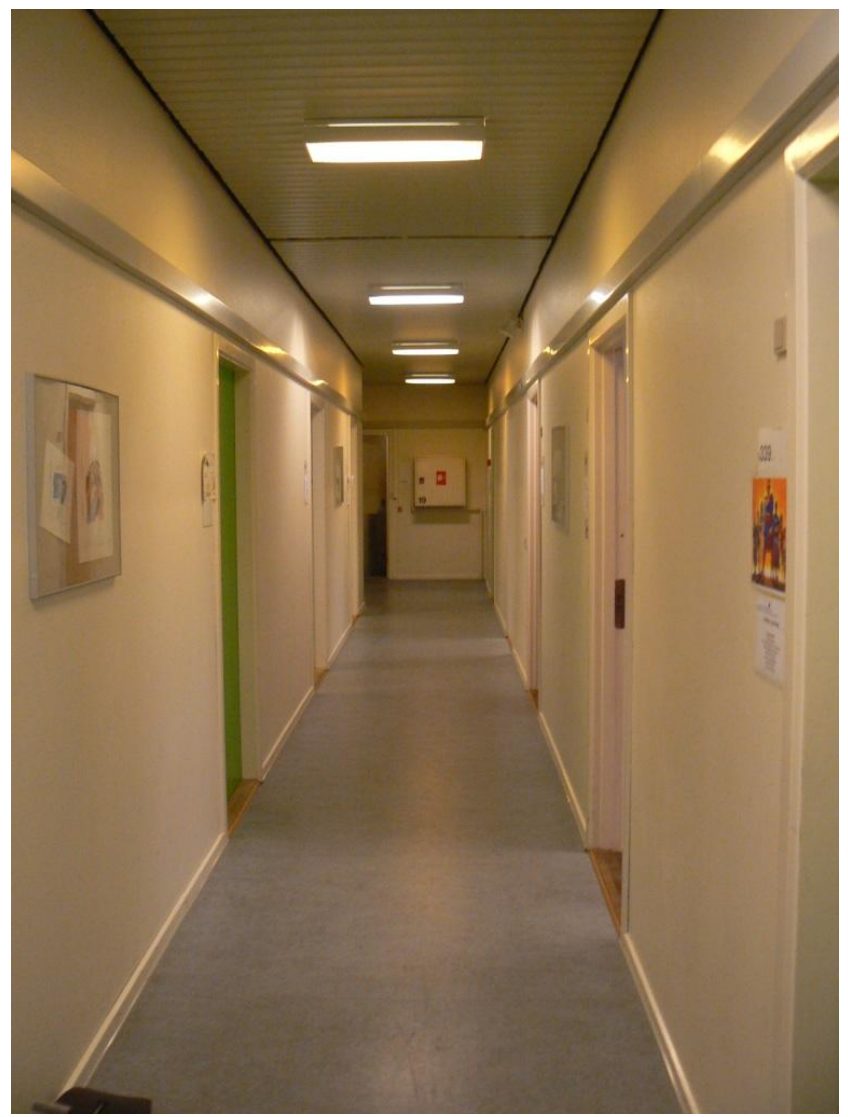

ชี

Figur 2. De individuelle lukkede grupperum (SGR) grænser op til en lang, forholdsvis smal korridor, præget af lukkede døre.

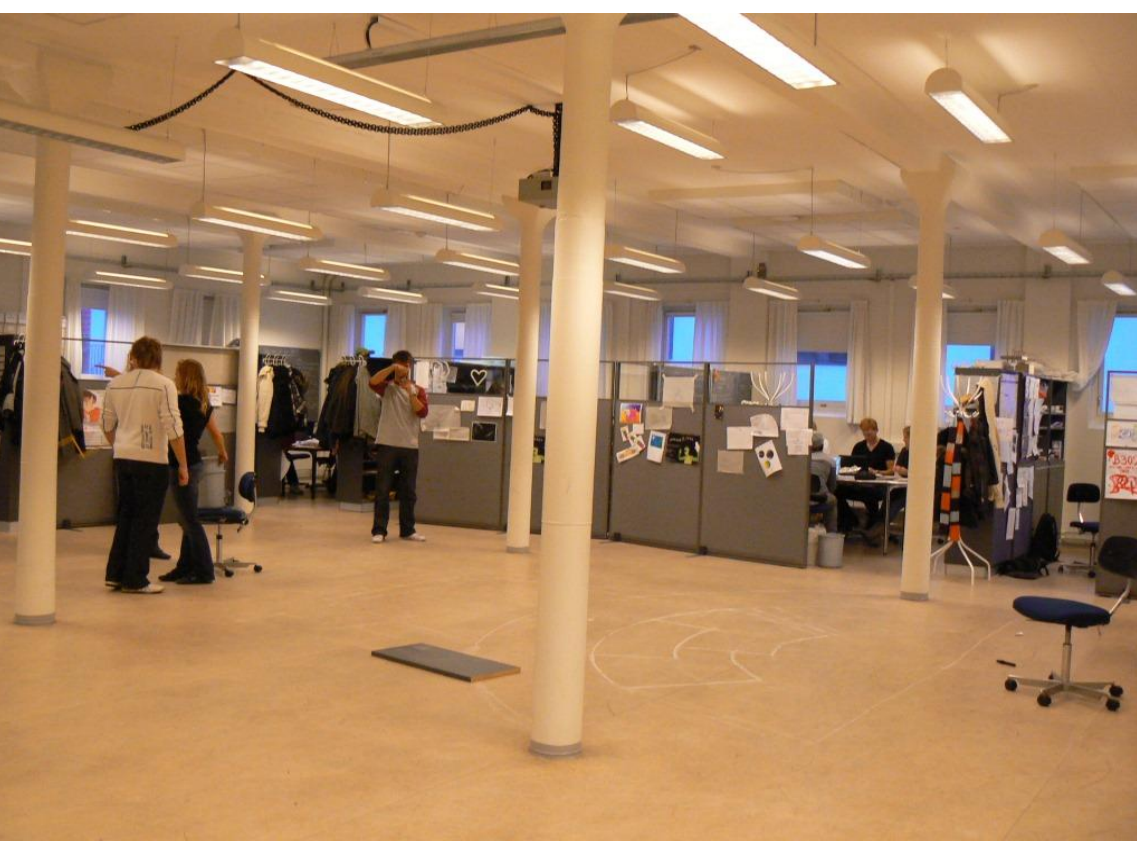

Figur 3. Projektorganiseret undervisning i halvåbne grupperum på fxlles tegnesal (MGR). Rummene er delvis åbne, adskilt med fleksible halvvægge og grænser ud til et åbent fxllesareal. 
Metodisk anvendes et design, hvor deltagende observation kombineres med spørgeskemaundersøgelse. Den deltagende observation kan gennemføres med varierende grad af forudbestemt fokus på, hvad der observeres og involvering med feltet (Dewalt, Dewalt \& Wayland, 1998; Keiding, 2011, b; Weick, 1985). De metodiske overvejelser har efterfølgende dannet grundlag for genbeskrivelse af deltagende observation (Keiding, 2011b). I det aktuelle feltstudie er valgt en tilgang, hvor der fokuseres på den konkrete brug af rummene og de studerendes interaktion med hinanden. Observationerne suppleres med uformelle samtaler med de studerende om deres oplevelser af rummene samt deres samspil med hinanden. Der er med andre ord tale om en vis grad af involvering i feltet. Vi undgik konsekvent at spørge til læring og læringsoplevelser for at undgå at lede de studerendes svar i denne retning. Data består af feltnoter og en omfattende fotodokumentation (163 billeder fordelt på to observationsgange, hhv. 20. 11. 07 og 12. 12. 07). Feltarbejdet blev udført af forfatteren samt af to studentermedhjælpere, som også renskrev og samlede feltnoter.

Rummenes indflydelse på de studerendes læringskontekst indkredses derudover gennem et spørgeskema uddelt til alle. Der kom 50 besvarelser retur svarende til en svarprocent på 38. Det er en forholdsvis lav svarprocent, men de uformelle interviews med grupperne bidrog ikke med nye informationer, hvorfor resultaterne kan ses som repræsentative for hele holdet.

Spørgeskemaet indkredsede læringskonteksten gennem 5 åbne spørgsmål: Hvad oplever du som fordele ved MGR? Som fordele ved SGR? Og tilsvarende blev de spurgt om oplevede ulemper ved MGR og SGR samt hvor meget de kendte til de andre gruppers projekter. Hertil kom et lukket spørgsmål om, hvilken rumtype de foretrak. Tilsvarende feltstudiet anvendes ikke begreber som læring, læringsmiljø eller studiemiljø i spørgsmålene.

Spørgeskemabesvarelserne analyseres som tekst, som beskrevet i Rasmussen (2004). Analysen falder $\mathrm{i}$ to trin. I første trin kategoriseres de studerendes beskrivelser af deres oplevelser af henholdsvis fordele og ulemper med to rumtyper. I andet trin udvælges alle udsagn, der kan tilregnes temaet inspirerende interaktion. De selekterede udsagn kategoriseres efterfølgende i de tre meningsdimensioner (sags-, tids- og socialdimensionen), som er beskrevet i Luhmann (2000). Dette sker for at få indblik i, hvad der i de studerendes optik er centrale dimensioner i en inspirerende læringskontekst, og på hvilken måde disse dimensioner udfolder sig i de to forskellige studiemiljøer.

I teksten er citater identificeret ved $Q$ for spørgeskema samt spørgeskemaets nummer, således at Q1 er et citat fra spørgeskema nummer 1. Citater fra observationsnoterne er mærket med OBS samt dato for observationen. I Keiding (2011a) findes flere eksempler på de studerendes udsagn, som af pladsmæssige hensyn må udelades her 
Det konkrete materiale tillader ikke at generalisere ud over det aktuelle studie. Betegnelsen "de studerende" henviser således til de studerende på det aktuelle hold. I artiklens sidste del diskuteres resultaterne fra dette studie op mod udvalgte eksempler fra litteraturen.

\section{Rummet som med- og modspiller i forhold til faglig inspiration og feedback.}

For begge studiemiljøers vedkommende kan fordele og ulemper sammenfattes i to kategorier: Inspiration/feedback fra medstuderende og støj/forstyrrelser.

De studerende beskriver fordelen ved MGR som den lette adgang til, ja nærmest uundgåelige, inspiration og feedback fra medstuderende og disses projekter. De studerende taler om såvel uformel som formel inspiration. Den uformelle inspiration opstår ved, at de spontant mødes i fællesområdet foran gruppearbejdspladserne; ved at de ser andre gruppers skitser og modeller; ved at de "stikker hovedet ind" til en anden gruppe eller ved blot at overhøre andre gruppers samtaler. Den formelle inspiration skabes ved, at grupperne træffer aftaler om at diskutere deres projekt med hinanden.

Ulemperne ved MGR knytter sig til afbrydelser og støj fra medstuderende. Der er dog markante forskelle på, hvorledes de studerende oplever lyden af deres medstuderendes aktiviteter. Beskrivelserne spænder fra "generende støj" (Q46) til "let summen af kreativitet" (Q40).

Flertallet af de studerende værdsætter mulighederne for faglig interaktion højere end de ulemper de oplever ved MGR. Kun en enkelt siger, at rummet tilbyder muligheder for faglig inspiration, men at gruppen ikke har fundet det relevant (Q27). Rummets potentialitet som inspirerende studiemiljø omsætter sig således ikke pr. automatik i en oplevelse af en læringskontekst præget af faglige inspiration og feedback.

De nærmest ubegrænsede muligheder for inspiration stiller de studerende over for en opgave med løbende at vurdere, hvornår de engagerer sig i forskellige inspirerende aktiviteter samt med efterfølgende at reflektere over, om og i givet fald hvorledes de sætter inspirationen i spil i eget projekt: “Man kan så sige, at det selvfølgelig også stiller krav til den enkelte om at stole på sig selv til tider" (Q48).

Fordelen ved SGR fremhæves som fravær af støj og forstyrrelser og deraf følgende bedre muligheder for at fokusere på projektet. Ulempen opleves entydigt som begrænsede muligheder for inspiration og feedback fra medstuderende. De studerende søger at skabe mulighed for uformel interaktion ved at træffe aftaler om at holde døren åben men konstaterer, at dørene ofte ender med at være lukkede. En studerende udtrykker sin opfattelse af de læringsmæssige konsekvenser således: “Det bli- 
ver en mere ensporet proces uden uformelle besøg; vi kommer til at lukke døren og skubber os væk fra de andres input, hjælp og samvær" (Q28).

Også i relation til SGR bliver det tydeligt, at studiemiljøet ikke skaber entydige læringskontekster. En enkelt studerende taler om, at hans gruppe er opmærksom på de begrænsninger, de fysiske rammer skaber for uformel inspiration og feedback, og derfor målrettet bestræber sig på at kompensere herfor samtidigt med, at de nyder godt af det lukkede rums muligheder for at skærme sig mod støj og forstyrrelser (Q20).

\section{"Os og dem" - om at være del af og have adgang til et fagligt fællesskab}

I analysens anden fase ses der nærmere på, hvad de studerende tillægger betydning for, at der opstår en inspirerende interaktion.

I forhold til interaktionens sagsdimension viser analysen, at inspiration fra medstuderende og andre projekter ikke er knyttet til, at andre projekter minder om ens eget, og om man derfor direkte kan bruge dele heraf i eget projekt. Tværtimod er de studerende opmærksomme på både at lade sig inspirere og på at holde fast i deres eget projekt. I kraft af den fastlagte projektramme udfolder alle projekter sig dog inden for et overordnet, fælles tema. Dette kan bidrage positivt til relevansen af de indtryk, der kan fås ved at iagttage andre projekter, fordi projekterne - trods markante indbyrdes forskelligheder - overordnet set forholder sig til den samme uddannelsesmæssige problemstilling. ${ }^{2}$

I forhold til tidsdimensionen er de studerende opmærksomme på, at der kan være tidspunkter, hvor inspirationen enten ikke skal opsøges eller sættes i spil i eget projekt. Man kan simpelthen være et andet sted i ens egen læreproces eller i det projekt, man deltager $\mathrm{i}$.

Der kan, hverken hvad angår sags- eller tidsdimensionen, identificeres forskelle knyttet til rumtype i opfattelsen af, hvad der skaber et inspirerende studie- og læringsmiljø.

Derimod er der store forskelle på, hvorledes de studerende beskriver interaktionens socialdimension. De studerende i MGR beskriver sig selv som værende en del af et større fællesskab. De kender hinanden og føler sig fri til at gå ind til andre grupper stort set når som helst. Man tør spørge om hjælp hos andre, fordi man kender hinanden. De andre grupper omtales ofte som naboerne, og betegnelsen vi bruges både som henvisning til egen projektgruppe og til alle grupperne i MGR. Brugsretten til de

\footnotetext{
${ }^{2}$ Der skelnes konsekvent mellem læring på individniveau, dvs. som læring som forandring af mentale systemer, og projekters læring, som forandring af sociale systemer (Keiding, 2008). Distinktionen mellem projektets uddannelsesmæssige hensigt og projektets konkrete hensigt er udfoldet samme sted.
} 
gruppespecifikke arbejdspladser i det åbne rum synes ligeledes at blive præget at stigende fleksibilitet hen over semestret. I den sidste travle periode bruges andre gruppers rum, hvis der er ledigt. I observationsnoterne er det beskrevet som, at "rummene udvides og den private zone udviskes og blandes med de andres" (OBS141207).

I SGR området taler de studerende derimod om, at man ikke opsøger andre grupper, hvis døren er lukket. Når det endelig sker, føler de, at de trænger sig ind på et privat område: "Det var meget lidt jeg kiggede ind i de andre grupperum fordi man nærmest bryder ind i et privat rum ved at åbne døren"(Q22). Man er gæst hos de andre, hvilket, ud over de beskrevne reservationer for at opsøge inspiration og feedback, fører til oplevelser af at være isoleret og uden andet fagligt fællesskab end egen projektgruppe: “Det virkede helt forkert at skulle gå ind til andre grupper" (Q34).

Den manglende oplevelse af fagligt fællesskab kommer også direkte til udtryk gennem det forhold, at betegnelsen vi udelukkende benyttes med reference til egen gruppe. Oplevelsen af fremmedhed i forhold til de andre grupper og opfattelsen af at tilhøre én og kun én gruppe åbner således for en dem/os-optik, som er grundlæggende forskellig fra den vi-optik, som benyttes i MGR. Samme tematik berøres i forhold til hjemmet og døren som markering af grænsen til den private zone i Winther (2005).

\section{Rum og rammesætning af interaktionen}

Selvom der ikke er en entydig sammenhæng mellem det fysiske studiemiljø og den individuelle oplevelse af rummet som læringskontekst, er det tydeligt, at de studerende, som deltager i undersøgelsen, generelt oplever, at MGR skaber bedre betingelser for faglig inspiration og oplevelse af at høre til end SGR. Ikke fordi de studerede i SGR ikke ønsker den faglige og sociale kontakt, men fordi ubehaget ved at krydse, hvad de oplever som en grænse til et privat rum, hindrer dem i at opsøge den. Et sådant mønster kan forstærke sig selv. Tanken om ubehaget ved at trænge ind $i$ et privat rum afholder de studerende fra at forsøge, hvilket bidrager til yderligere privatisering af rummene. En konsekvens kan blive faglig selveksklusion (Keiding \& Vardinghus, 2004).

Selvom undersøgelsen ikke tillader generalisering ud over det aktuelle studie, er det relevant at diskutere resultaterne op mod anden forskning.

I Bakke (2007) beskrives det, at rum kan støtte op om eller virke hindrende for en bestemt interaktion og, at et rums funktionalitet er tæt knyttet til, hvad der helt konkret foregår i rummet. Men rum kan ikke determinere interaktionen. Samme forståelse af samspil mellem rum og interaktion skrives frem i Kirkeby, Gitz-Johansen og Kampmann (2005) gennem anvendelse af affordance-begrebet. 
En af konklusionerne i Bakke (2007) er, i tråd med det aktuelle studie, at mulighederne for spontan, uformel kontakt er afgørende for videndeling på tværs af medarbejdere. Dette adskiller sig markant fra andre undersøgelser af læringsoplevelser i storrumskontorer, som peger på, at medarbejdere ikke oplever øget inspiration og feedback fra deres kolleger (Pejtersen, 2006). En af forklaringerne kan være, at studerende lige som i de vidensorienterede arbejdsprocesser, som Bakke (2007) fokuserer på, ser læring som et afgørende udkomme af deres aktiviteter. De er med andre ord in it for the learning, mens læring på andre typer af arbejdspladser kan antages i højere grad at være underordnet et produktionsorienteret rationale.

Et andet interessant perspektiv knytter sig til spørgsmålet om rummets muligheder for at støtte og fastholde studierelateret kommunikation. Ser man på mange af de nyere eksempler på studiemiljøer, der sigter mod at skabe rammer for studentercentrerede aktiviteter (UBST, 2009; Horst \& Misfeldt, 2010), er det tydeligt, at både MGR og SGR adskiller sig afgørende fra disse i kraft af, at hver gruppe er tildelt en fast studieplads. Hermed skabes mulighed for og gøres aktivt brug af rummets muligheder for at fastholde og synliggøre projektrelevante informationer i form af skitser, tidsplaner mv. (Se figur 1 og 3).

Rummene bidrager således til at etablere et ikke-flygtigt kommunikativt stillads omkring læreprocesserne og bliver dermed både et aktivt element i projektets hukommelse og bidrager til et fælles fokus i kommunikationen. Behovet for at kunne arbejde med en fælles præsentation af den aktuelle opgave synes størst i gruppebaseret undervisning, hvor det fælles objekt kan bidrage til at synkronisere kommunikationen på en helt anden måde, end hvis alle sidder med hver deres individuelle repræsentationer.

I mange tilfælde kan studiemiljøer ikke tilbyde denne stilladserende funktion. Enten fordi de ikke har vægge, og/eller fordi de benyttes af forskellige deltagere, og derfor ryddes for studierelateret indhold, når de forlades. Der kan derfor være relevant at se på, hvorledes man, eksempelvis gennem brug af it-baserede teknologier, kan udforme studierum, som kan tilpasses de aktuelle brugere, frem for at brugernes interaktion og arbejdsmåder må tilpasse sig rummet.

\section{Lærings- og samarbejdskompetencer som mulig medlæring}

Lige som rummet ikke determinerer interaktionen og den enkelte studerendes oplevelse af rummet som kontekst for læring, kan der ikke sluttes direkte fra læringsoplevelser til læringsudbytte. Hvilke læringsmæssige spor en given oplevelse sætter sig afhænger - set ud fra en konstruktivistisk læringsforståelse - af, hvorledes den konkrete læringsoplevelse forbindes med eksisterende viden og benyttes i fremtidige interaktioner med omverdenen. På den anden side er det tydeligt, at omgivelserne indvirker på individets læring (Luhmann \& Schorr, 1982, s. 7). Og resultaterne rejser 
for mig at se flere didaktiske spørgsmål. Her vil jeg koncentrere mig om de to studiemiljøers potentiale til at støtte udvikling af deltagernes lærings- og samarbejdskompetencer.

Kravet om at kunne vedligeholde egne kundskaber og samarbejde på tværs af fagmiljøer indgår som et centralt tema i kvalifikationsrammen for videregående uddannelser (Styrelsen for Universiteter og Internationalisering, 2011). Læringskompetence handler i professionelle sammenhænge både om at tilegne sig ny viden og om at kunne selektere og vurdere, hvad der skal vides hvornår og af hvem. Analysen antyder, at projektarbejdet i MGR stimulerer de studerende læringskompetencer. Hvad angår egen læring, udfordres de studerende i MGR både på at udvikle og reflektere egen viden gennem mødet med andre studerende og disses projekter og på at kunne være selektive i forhold til, hvornår en inspirerende oplevelse skal danne afsæt for nye læreprocesser, og hvornår den blot skal være en inspirerende iagttagelse. I forhold til projektet udfordres de på løbende at vurdere, hvilke inspirationer og ny viden de skal holde for sig selv, og hvilke der aktuelt kan bidrage positivt til projektet og derfor skal formidles ind i projektet. De udfordres med andre ord på, at udvikle (fag-) didaktisk kompetence på både individuelt og projektniveau.

Hvad angår samarbejdskompetence, antyder den empiriske undersøgelse, at de to studiemiljøer overordnet set skaber ganske forskellige erfaringer med og forudsætninger for at kunne samarbejde og dele informationer på tværs af projekter. I SGR, forbindes det at tage kontakt til medstuderende af mange med ubehagelige oplevelser af at trænge sig på og forstyrre. Sådanne oplevelser åbner for to former for uønsket medlæring. For det første at de studerende i SGR kun i begrænset omfang lærer at deltage i uformelle, professionelle læringssammenhænge. For det andet i form af faglig og professionel reserverthed som kan føre til, at den studerende også i andre professionelle sammenhænge afstår fra at være aktivt medskabende af såvel formelle som uformelle professionelle læringssituationer. Anden forskning peger i tråd hermed på, at stabile sociale grupperinger kan virke som barrierer for at såvel individer som grupper åbner sig for interaktion med omgivelserne (Waldström \& Lauring, 2006). Og netop fordi interaktionen med medstuderende er langt mere begrænset i SGR, er der en potentiel risiko for, at grupperne over tid bliver så stabile, at de kun i meget begrænset omfang tilskyndes til at bidrage til eller drage nytte af kollegers viden.

Modsat har MGR som nævnt potentiale for en løbende medlæring i forhold til at kunne samarbejde og informationsudveksle på tværs af projekter. Knytter man an til Weicks (2001) antagelse om, at mange arbejdsopgaver løses i løst koblede og dynamiske netværk, ses væsentlige ligheder mellem de samarbejdsformer, der udfolder sig i MGR, og de netværksorganiserede og kompleksitetstunge samarbejdsformer, 
som de studerende vil møde i deres professionelle karriere. Man kan derfor fortolke resultaterne af det empiriske studie sådan, at de studerende, der er placeret i MGR, udover den potentielle vidensmæssige gevinst mere eller mindre upåagtet lærer sig væsentlige uddannelses- og erhvervsrelevante lærings- og samarbejdskompetencer. En sådan ikke-intenderet medlæring, eller socialisering om man vil, betegnes ofte som "skjult læreplan" (Dreeben, 1968), og en grundlæggende udfordring for uddannelsesforskningen er at undersøge såvel intenderede som ikke-intenderede følgeeffekter af uddannelse og undervisning.

Tina Bering Keidings forskningsfelt er undervisning og didaktik, primært inden for videregående uddannelser. Det langsigtede mål er at formulere et sammenhængende, analytisk og teoretisk konsistent, alternativ til de aktuelle didaktiske teorier. Aktuelt ligger tyngden på indholdsbestemmelse i universitetsuddannelser samt på den studentercentrerede undervisning, primært i form af projektorganiseret undervisning.

\section{Referencer}

Bakke, J. W. (2007) (red.). The Nordic Knowledge Workplace: Learning and Room. Nordic Innovation Centre. http://www.alexandra.dk/dk/labs/New-Ways-of-WorkingLab/Documents/02132 dekar a nordic guide to workplace design.pdf (01.06.2012).

de Coninck-Smith, N. (2011). Barndom og arkitektur: Rum til danske børn gennem 300 år. Aarhus: Klim.

Dewalt, K. M., Dewalt, B. R. \& Wayland, C. B. (1998). Participant observation. I Bernard, H. R. (red.). Handbook of Methods in Cultural Anthropology, pp. 259-300. Oxford: Alta Mira.

Dreeben, R. (1968). On What is Learned in School. Reading Mass.: Addison-Wesley.

Gutman, M. \& de Coninck-Smith, N. (2008). Designing Modern Childhoods: History, Space, and the Material Culture of Children. London: Rutgers.

Helmke, A. (2009). Unterrichtsqualität und Lehrerprofessionalität. Diagnose, Evaluation und Verbesserung des Unterrichts. Seelze-Velber: Klett Kallmeyer.

Horst, S. \& Misfeldt, M. (2010) (red.). Fremtidens undervisningsmiljø på universitetet. Baggrundsrapport. Institut for Naturfagenes Didaktik, Københavns Universitet \& Institut for Didaktik, DPU, Aarhus Universitet. http://www.ind.ku.dk/udvikling/projekter/undervisningsmiljo/Baggrundsrapport-FremtidensUndervisningsmilj_P Universitetet.pdf/ (01.06.12).

Keiding, T. B. (2008). Projektmetoden - en systemteoretisk genbeskrivelse. Dansk Universitetspædagogisk Tidsskrift 3 (5), 22-29.

Keiding, T. B. (2010). Rum og undervisningsformer. I Horst, S. \& Misfeldt, M. (red.) Fremtidens undervisningsmiljø på universitetet. Baggrundsrapport. Institut for Naturfagenes Didaktik, Københavns Universitet \& Institut for Didaktik, DPU, Aarhus Universitet. http://www.ind.ku.dk/udvikling/projekter/undervisningsmiljo/Baggrundsrapport-FremtidensUndervisningsmilj P Universitetet.pdf/ (01.06.12).

Keiding, T. B. (2011a). Spatial conditions: an unheeded medium in teaching and learning. E-Learning and Digital Media 8 (3), 197-213. 
Keiding, T. B. (2011b). Observing participating observation: Re-description based on systems theory. Forum: Qualitative Social Research, 11 (3), art. 11.

Keiding, T. B. \& Laursen, E. (2008). Projektmetoden iagttaget. Metodens didaktik og anvendelse i universitetsuddannelse. Aalborg Universitet, Institut for Uddannelse, Læring og Filosofi. http://www.learning.aau.dk/index.php?id=9065\#c30292 (01.06.12).

Keiding, T. B. \& Vardinghus-Nielsen, H. (2004). Inklusion/eksklusion: Et perspektiv på en flex-klasse på et studenterkursus. I Mathiasen, H. (red.) Det virtuelle gymnasium - 2. del af følgeforskningsrapport om et udviklingsprojekt. Udviklingsprogrammet for fremtidens uddannelser. S. 75-100. København: Uddannelsesstyrelsen.

Kirkeby, I. M. (2003). Fremtidens Universitet. Videnindsamling og skitserede programanalyser. København: Rum Form Funktion, Statens Forsknings- og Uddannelsesbygninger. http://www.ubst.dk/publikationer/fremtidens-universitet/FU.pdf (01.06.12).

Kirkeby, I. M., Gitz-Johansen, T. \& Kampmann, J. (2005). Samspil mellem fysisk rum og hverdagsliv i skolen. I Larsen, K. (red.) Arkitektur, krop og læring. København: Hans Reitzel.

Larsen, K. (2005) (red.). Arkitektur, krop og læring. København: Hans Reitzel.

London Metropolitan University (i.å). Science Center. http://www.londonmet.ac.uk/depts/fls/sc/(01.06.12).

Luhmann, N. (2000). Sociale systemer. Kbh: Hans Reitzel.

Luhmann, N. \& Schorr, K. E. (1982). Zwischen Technologie und Selbstreferenz. Fragen an die Pädagogik, Frankfurt am Main: Suhrkamp.

Meyer, H. (2005). Hvad er god undervisning? Kbh: Gyldendals Lærerbibliotek.

Pejtersen J. (2006). Støj i storrumskontorer. Arbejdsmiljøinstituttet. http://www.arbejdsmiljoforskning.dk/upload/JHP 10102006.pdf (01.06.12).

Rasmussen, J. (2004). Undervisning i det refleksivt moderne. Kbh.: Hans Reitzel.

Ricken, W. (2010). Arkitektur, Pædagogik og Sundhed - Samspil mellem læringsaktiviteter og fysiske rum i relation til handlemuligheder og udvikling af handlekompetence. København: Kunstakademiets Arkitektskole, Center for Idræt og Arkitektur.

http://www.learningspaces.dk/data/archive/files/WinieRicken phd final print. pdf $(01.06 .12)$.

Styrelsen for Universiteter og Internationalisering (2011). Niveauer $i$ Kvalifikationsrammen for Livslang Læring http://www.iu.dk/dokumentation/kvalifikationsrammer/niveauer/Niveaubeskrivelser DA.pdf (01.06.12).

UBST (2009). Campus og Studiemiljø. Fysiske rammer til morgendagens universiteter. Kbh.: Universitets- og Bygningsstyrelsen, Ministeriet for Videnskab, Teknologi og Udvikling.

Waldström, C. \& Lauring, J. (2006) Sociale netværk som barrierer for videndeling. Ledelse og Erhvervsøkonomi. 1, 28-40.

Watson, L. (2006). The Saltire Centre at Glasgow Caledonian University. Sconul Focus (37), 4-11. http://www.sconul.ac.uk/publications/newsletter/37/2.pdf (01.06.12).

Weick, K. (1985). Systematic observation methods. I Lindzey G. \& Aronson E. (red.). Handbook of social psychology. Vol. 1, Theory and method pp. 567-634. New York: Random House. 
Weick, K. E. (2001). Making Sense of the Organization. Malden, MA: Blackwell Publishers.

Winther, I. W. (2005). Hjemmeregler. I: K. Larsen (red.). Arkitektur, krop og læring. København: Hans Reitzel. 